\title{
Indigenous Agroforestry Practices in Southern Ethiopia: The Case of Lante, Arba Minch
}

\author{
Molla Mekonnen Alemu \\ University of Leicester, Leicester, UK \\ Email: mollamekonnen@gmail.com
}

How to cite this paper: Alemu, M.M. (2016) Indigenous Agroforestry Practices in Southern Ethiopia: The Case of Lante, Arba Minch. Open Access Library Journal, 3: e3278.

http://dx.doi.org/10.4236/oalib.1103278

Received: December 5, 2016

Accepted: December 23, 2016

Published: December 26, 2016

Copyright $\odot 2016$ by author and Open Access Library Inc.

This work is licensed under the Creative Commons Attribution International

License (CC BY 4.0).

http://creativecommons.org/licenses/by/4.0/

\begin{abstract}
Agroforestry has been practiced for centuries in different parts of the world by making use of indigenous technical knowledge. Since societies have lived for long period of time in a specific area, indigenous knowledge has been transferred from generation to generation by building on new inventions on what has been inherited across years. The practice has served communities to find indigenous medicinal plants; edible fruits, leaves, roots and steam; fuel; feed for livestock; shelter; construction materials; ameliorating micro climates; and many more. The southern part of Ethiopia is endowed with indigenous agroforestry practices that have evolved over years. The agroforestry activities of the communities have enabled to maintain the greenery of the region along with its magnificent contribution towards ecological values, food security and local economic benefits. This study was held in Lante, one of the Kebeles (the smallest administration unit) of Arba Minch Zuriya district of Southern Ethiopia so as to explore the indigenous agroforestry practices along with its present contribution for food security and local economic development. Primary and secondary data were collected by making use of interview questions and review of related literature. Then data were transcribed and analysed by descriptive statistics. Findings of the study showed that home garden, intercropping and livestock based agroforestry practices of the area are contributing a lot in maintaining food security at the household level through the provision edible items from backyard throughout the year. It has also enabled the communities to be empowered economically as they can always find to be cashed and fulfill household needs. Thus, since the case of Lante is a good role model for sustainable agroforestry development, sharing the indigenous agroforestry experience with the rest of the country could have a great impact in building green economy at grassroots levels.
\end{abstract}

\section{Subject Areas}

Environmental Economics, Marketing 


\section{Keywords}

Indigenous Knowledge, Agroforestry, Lante, Home Garden, Intercropping,

Livestock, Southern Ethiopia

\section{Introduction}

Indigenous communities have developed knowledge of ecosystem management that has evolved through an intricate manner. These ecosystems are serving by being source of food, shelter, energy, construction materials, etc. The ecological benefit which sustained the survival of life forms on the surface of the earth is also maintained as a result of the services obtained from ecosystems [1].

Evidence shows that many of the indigenous communities and practitioners have continued on the traditional management ways and practices of natural resources. The wealth of knowledge from the indigenous agroforestry practitioners provides the level and depth knowledge that has developed over centuries among the indigenous people. Agroforestry has played and is still playing a key role in the conservation and management of land resources in a sustainable way. Agroforestry ecosystems harbour a variety of life forms functioning together which in turn provide the services that enable the wellbeing of humanity and other life forms.

Agroforestry, the integration of trees in agricultural activities has the capacity to increase soil fertility, nutrient recycling, reduce evaporation, and reduce land degradation from erosion, carbon sequestration and improvement of water quality. These benefits will have an impact and environmental benefits contribution at the farm scale, local and regional levels. Agroforestry practices in general will help to maintain the wellbeing of societies at all levels [2].

Agroforestry practices are also believed to contribute for the Millennium Development Goals of the United Nations in various ways. The practices have helped to fight hunger by the deployment of agroforestry based soil fertility and land management methods. The average proportion of the food insecure world population has decreased from $37 \%$ to $18 \%$, and the availability of food has enhanced in the developing world. Trees have also a magnificent contribution in fixing nitrogen that can increase agricultural productivity. Many of the rural poor are able to generate income through the production of trees which has created the enabling environment for ease of access to health services and nutritional sources. Agroforestry practices have also contributed a lot in the protection of watershed services and maximize the production systems [3].

The role of agroforestry on current Sustainable Development Goals of the United Nations through climate change adaptation and mitigation is getting explicit. No single approach of food security will be productive without the ecological and economic contribution of trees. It requires the integrated approach of sustainable land use models in order to lift up the living standards of the wider agriculture based portion of the world 
population. Agroforestry is a proven model of integrated sustainable land use system which can enhance agricultural productivity and production in a low input and in an ecological and economically feasible way in the effort of enhancing food security sustainably [4].

Indigenous agroforestry has been and still is a dominant land use practice in the Southern Nations, Nationalities and People's Regional State of Ethiopia by forming the major component of the farming system. The region is known for its diverse and immense biodiversity resources that contributed for healthy ecosystem functions, sustainable livelihoods development and enhanced food security status of the region [5].

The Government of Ethiopia Climate Resilient Green Economy Strategy also outlines the integration of agroforestry systems in to forage legumes, croplands, expansion of green energy sources, forest and biodiversity conservation are believed to ensure the sustained development of the indigenous agroforestry practices of the country.

This will also develop and enhance the country's contribution towards the global efforts of global mitigation of greenhouse gases whilst it helps to ensure the inclusive growth by improving the resilience of the poorer communities towards the effects of climate change [6].

Lante Kebele of Arba Minch Zuriya district is known for its immense and rich indigenous agroforestry practices and biodiversity resources in the area. This study was, therefore, held in Lante in order to explore the indigenous agroforestry practices so that the knowledge and practices of the locality can be conserved and scaled up in other parts of the country and beyond.

\section{Ecosystem Services of Agroforestry Practices}

The general model of agroforestry practices considers shrubs, crops, perennials, trees, livestock, etc. as a basic element to it. Hence, agroforestry systems can be categorized as silvopastoral (forestry with domestic animals), agrisilvicultural (growing crops and trees) and agrosilvopastoral (crops, forestry and animals). Each system can be composed of different agroforestry practices that can be practiced in a particular location or region where there will be environmental, biological and economic linkages and interactions within the different tree and non-tree elements of the system. The agroforestry practices on the other hand can also indicate the specific land resources management activities in spatial and temporal arrangements [7] [8].

The Food and Agriculture Organization of the United Nation [9] had defined agroforestry as "a collective name for land-use systems and technologies where woody perennials (trees, shrubs, palms, bamboos, etc.) are deliberately used on the same landmanagement units as agricultural crops and/or animals, in some form of spatial arrangement or temporal sequence. Agroforestry can also be defined as a dynamic, ecologically based, natural resource management system that, through the integration of trees on farms and in the agricultural landscape, diversifies and sustains production for increased social, economic and environmental benefits for land users at all levels". 
Agroforestry systems and practices are providing various ecosystem services and environmental benefits that have local and regional importance [2]. The benefits of agroforestry practices also can have an economic dimension since it helps to maximize agricultural production by reducing soil erosion, water and organic matter losses. Through organic matter development and maintenance, the practices can increase microbial activities which can help nutrient recycling which can increase the fertility of soil under agricultural production. This can also improve the physio-chemical characteristics of the soil which can result for a better infiltration potential of the soil. They do have also an important role in reducing acidification and salinization related soil toxicities. As many of the indigenous communities are highly reliant on indigenous medicines extracted from trees, the practices have played and are playing a significant role in maintaining the health of communities in a productive way. In line with this, planting of trees in crop lands is also known to reduce insect pest and disease infestation. Nitrogen fixing trees can also increase agricultural production and thereof reduced cost for agricultural inputs [10].

The Government of Canada Agriculture and Agro-food Agency [11] mentioned as agroforestry practices are essential resources to combat climate because of their role in sequestering carbon and other greenhouse gases. It estimated as a mature poplar tree can help to sequester $266 \mathrm{kgs}$ of carbon and a white spruce tree will sequester $143 \mathrm{kgs}$ of carbon. It is also worthy to note that these figures doesn't include the amount of carbon which will be stored in the roots below the ground that could amount $50 \%-75 \%$ of the total stored on the other parts of the tree above the ground. These figures do not include the carbon stored in the roots, which may be equal to 50 to 75 per cent of the carbon stored above ground. Apart from this, agroforestry practices are also known to increase the biodiversity resource potentials. In particular, since they provide shelter and food, they are known to support the existence of wildlife.

\section{Methodology}

\subsection{Description of the Study Area}

Lante, the study area is one of the localities in Arba Minch Zuriya district of GamoGofa Zone which is located in the Southern Nations and Nationalities Peoples' Regional State of Ethiopia. Situated in the Great Rift Valley region, the district is located about $505 \mathrm{~km}$ south west of Addis Ababa. The district has a total of 29 Kebeles (the smallest administration unit in the country). Agro ecologically 4 kebeles are highlands, 15 kebeles at mid altitude and the rest 10 are found in the low land zone with a rainfall amount of 800 $\mathrm{mm}-1200 \mathrm{~mm}$ per annum. The temperature also ranges from $16^{\circ} \mathrm{C}-37^{\circ} \mathrm{C}$. There are two cropping seasons, namely, Belg (short rainy season from March to May), Meher (main rainy season of June to September). Lante being one of the Kebeles located in the lowland areas has a total population of about 7479 (female 3844). The Kebele has an average altitudinal range of 1175 - 1267 meter above sea level. Lante is also bordering with Lake Abaya which has a great contribution towards its potential for agroforestry and other agricultural activities [12] [13] (Figure 1). 


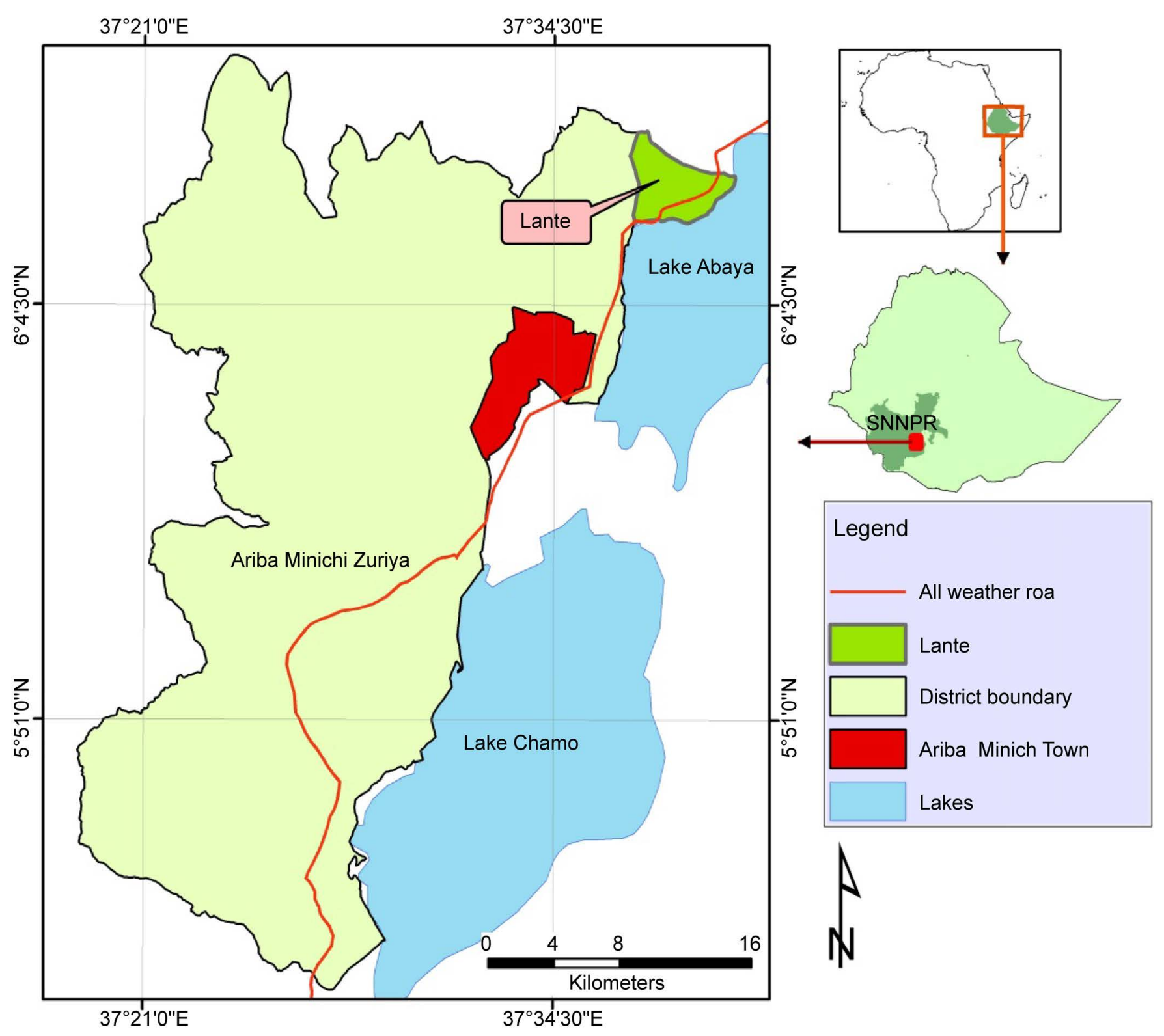

Figure 1. Location map of Lante [14].

\subsection{Data Collection and Analysis}

Semi-structured interviews with the local inhabitants and ground truthing observations were deployed as data collect instruments. Secondary sources of information such as literatures and reports were also reviewed. Discussions were also held with the concerned Government officials. A total of 62 community members (22 women) and 6 concerned government staff participated in the interview process. The different aspects of agroforestry such as the types of indigenous agroforestry practices, the perception towards the practices, threats, opportunities, etc. were explored during the discussions. Then data was transcribed and analyzed by making use of descriptive statistics on excel sheet and through content analysis. 


\section{Result and Discussion}

Indigenous agroforestry practices form the livelihoods history of Southern Ethiopia. It is a widely practiced activity in the region and that has helped the region to remain green while the rest of the country's woody vegetation is being degraded substantially. In the South it is not uncommon to see about ten different types of trees in the backyard of the smallholder farmers, mostly dominated by multipurpose species which have nutritional, economic and economic importance. Mango trees, Enset (false banana), Moringa, Papaya, etc. are among to mention (Table 1).

According to the respondents, as of very recent during the 'Derg' regime, the establishment of the socialist system based Producer's Cooperatives ('Ye-Amrachoch Hibret Sira Mahiber') also contributed a lot for the growth and expansion of agroforestry practices in the area. This is mainly because of the fact that, during that regime each individual household was allowed to own a very small area of land at their backyard for their private use as a result of the communalism of resources ideology that was strategized at that time. This phenomenon has forced farmers to stock and combine different species of trees which are of different use and livestock in that allowable plot of backyard land so as to supplement the food and other demands of the household.

\subsection{Major Agroforestry Practices}

Based on the findings of the study home garden, intercropping and livestock production were identified to be the major agroforestry practices of the area, the dominant being the home garden practice. The inhabitants are also deploying thinning, coppicing and other farm management indigenous practices on the fields. For instance, the communities are well acquainted with the indigenous ways of maintaining soil fertility from the leaf fall.

\subsection{Home Garden}

In the southern region of Ethiopia in general and Lante Kebele in particular home

Table 1. Land-use pattern of Lante.

\begin{tabular}{clc}
\hline S.N & \multicolumn{1}{c}{ Land-use type } & Area (hectare) \\
\hline 1 & Farm land & 613 \\
2 & Artificial forest & 15 \\
3 & Natural forest (bush and other trees) & 475 \\
4 & Wetland and marshy area & 110 \\
5 & Settlement & 80 \\
6 & Others & 367 \\
7 & Total & 1660 \\
\hline
\end{tabular}

Source: [13]. 
gardens are the widely practiced indigenous agroforestry activities. It is very common to observe multipurpose trees, fruit trees, and vegetables along with livestock in the backyard of many households. In this practice trees like Moringa are widely planted as they supplement the household's major source of meal throughout the year. Fruits like Mango, Papaya, Lemon, False banana ('Enset'), Orange, Avocado and Banana are also serving as sources of supplementary food and income generation opportunities. The smallholder farmers also plant Sugarcanes which is also another important source of cash for the household needs (Figure 2).

Vegetables such as capsicum, cabbage and sweet potatoes are also widely practiced as they form the major source of food in the community. In addition to this, cattle, chicken, donkeys, goats and sheep are reared in the backyard and the free gazing system of the locality. Coffee Arabica an important cash crop of the area is also grown under the shade of trees. The households also make use of live-fences made of bushes, Jatropha and other trees like Eucalyptus ('Chefeka'). Other trees such as Ficus and Olive species are also grown in the backyard since they serve as medicinal plants.

This practice has helped the smallholder farmers to maintain the local agro-ecology while they also managed to get nutritional sources of food within their own holdings. One elder when asked about the importance of agroforestry he mentioned "... it is like my savings in a bank, I can get edible items of different types whenever I need $i t$ !". In times of rainfall and water shortage, the trees will always be able to provide edible fruits since they will be able to get moisture from the underground water. Thus, agroforestry has played to cope up with disaster by building the resilience of the community in times of drought and rain failure. Based on the coping mechanism potentials of agroforestry and modern agriculture, the lion's share of the respondents showed their preference to continue agroforestry practices than field crops production. Some, however, also preferred the field crops production since they considered harvesting a reasonable amount of produce in a specific period of time as an advantage (Figure 3).
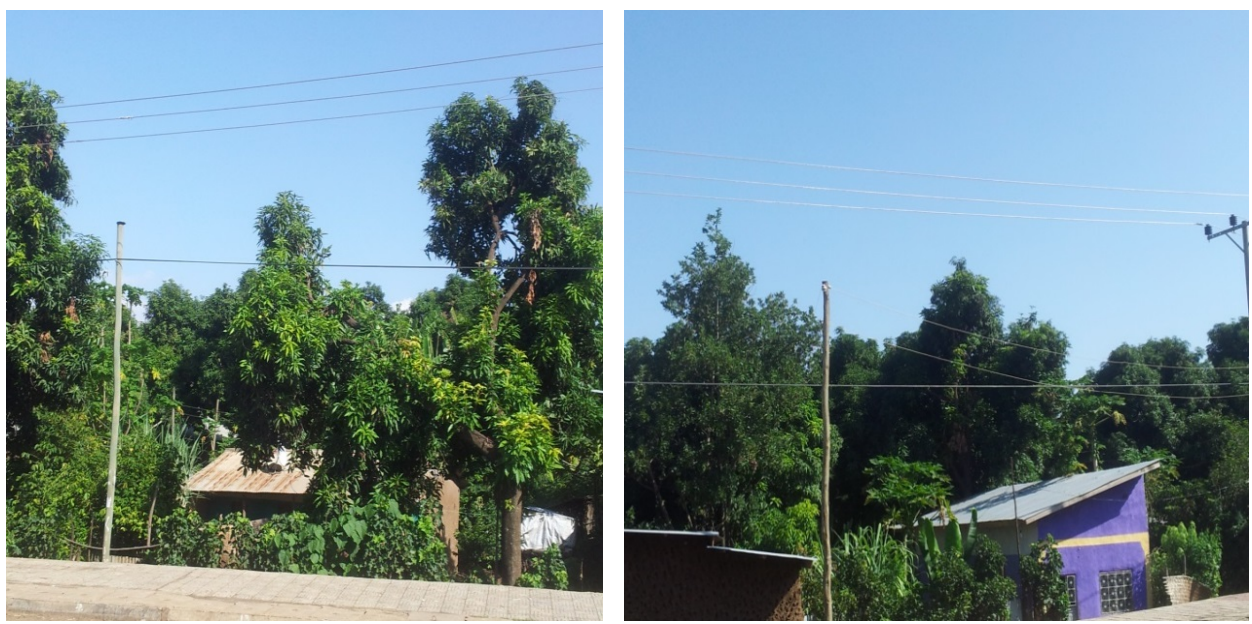

Figure 2. Typical home garden agroforestry practices in Lante. 


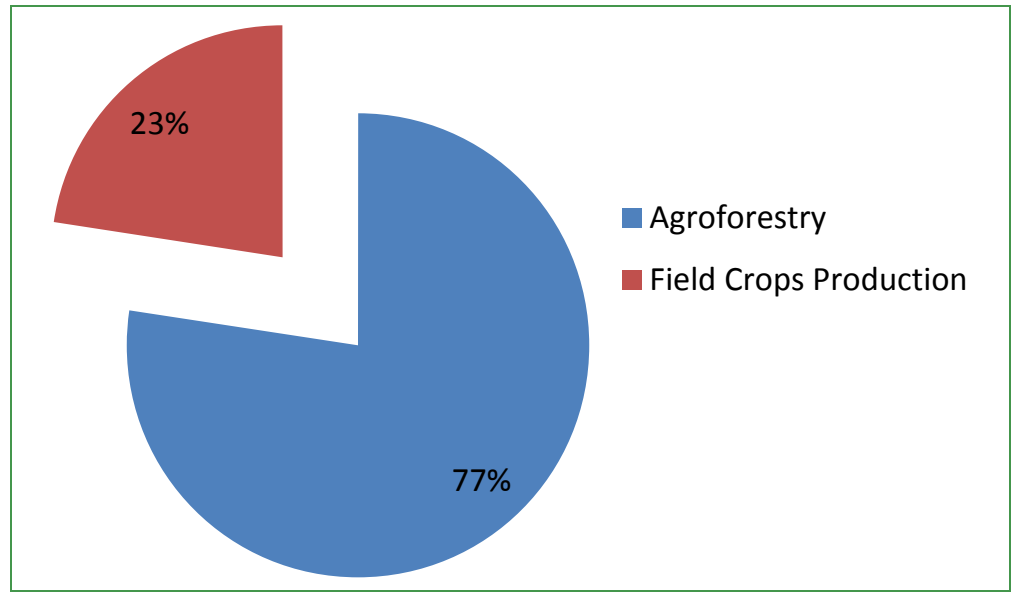

Figure 3. Respondents preference from agroforestry and modern agriculture.

\subsection{Intercropping Agroforestry Practices}

This practice is mainly carried out on farmlands. Ground truthing of this practice revealed as the intercropping activities have a tangible impact in maintaining soil organic matter, reduced evaporation from the soil surface as a result of the leaf fall mulch, shelter for shade loving plants such as coffee and also serves as shade for humans whenever working in the farm. The trees are believed to create conducive microclimate for the proper development of the undergrowth as they will be serving as windbreak and reducing the heat effects of the tropics overhead sun. The leaf fall which will stay on the surface also serves to lower down the devastating effects of rainfall drop splash and erosion. The litter mass is also believed to improve the physical characteristics of the soil and thereof better infiltration opportunities coupled with ground water recharging. This all can prove as agroforestry practices to play a pivotal role in offering ecosystem services which sustain the wellbeing of humans.

In this practice the most common activity is the cultivation of bananas with mango trees. The mango trees with their widespread canopy will reduce wind speed and there will also be less competition for nutrients as these plants have a different rooting system which will let them use soil nutrients and water from the different strata of the soil profile. Maize another important staple crop of the area is also cultivated in this system. In this practice the nitrogen fixing trees will also play in nutrient recycling and easing the production in an environment friendly and cost effective way.

Vegetable crops production is also another encouraging activity observed in the area. Farmers are intercropping trees with onions, capsicum, cabbage and sweet potatoes (Figure 4 and Figure 5).

\subsection{Livestock and Agroforestry Practices}

Livestock production forms the major part of the livelihoods of the rural communities. Farming activities such as ploughing and transport are being accomplished by making use of draft animals. Whilst free grazing is the widely practiced activity farmers also use 
cut and carry system in order to feed the animals at homesteads (Figure 6). The free grazing practice, however, has its drawbacks since the animals can at times go and graze on unprotected farm lands. The cow dung from the livestock population, once dry, serves as source of household energy since it will be used as fuel for cooking and heating activities of the household. Cattle production is the major livestock activity. Sheep and goats are widely reared in the area. Chickens are also reared around homesteads. Most of the produce and marketable items are transported on the back of donkeys and donkey drawn carts.

The perceptions survey of the agroforestry practitioner local communities indicated that the income generated from agroforestry practices is by far higher than other
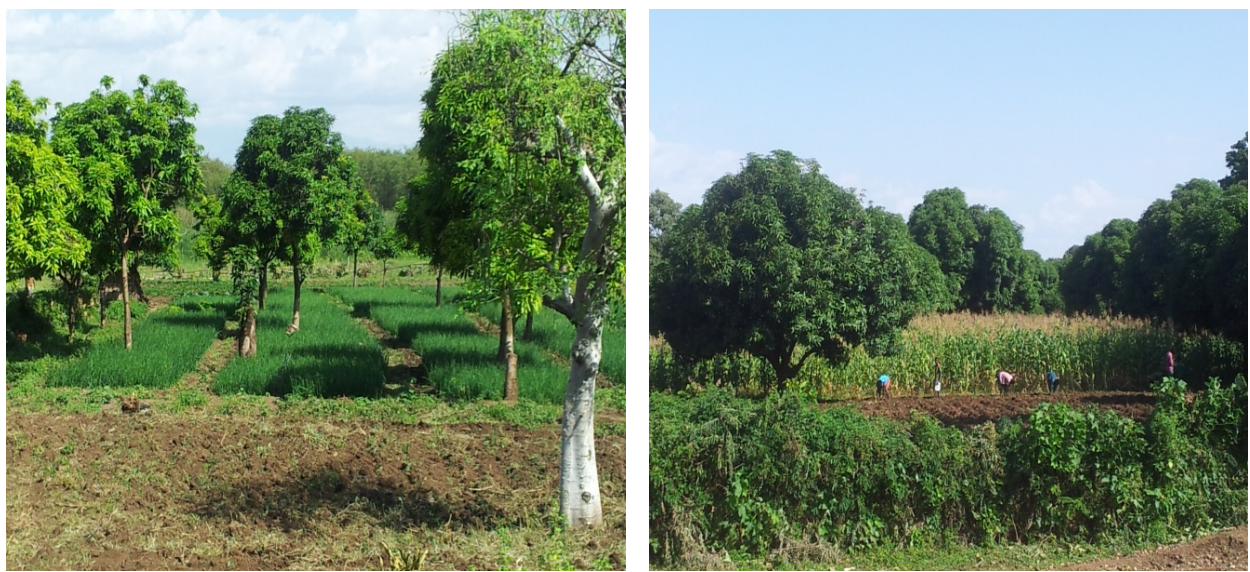

Figure 4. Intercropping (left—onions with trees, right—maize with mango trees).
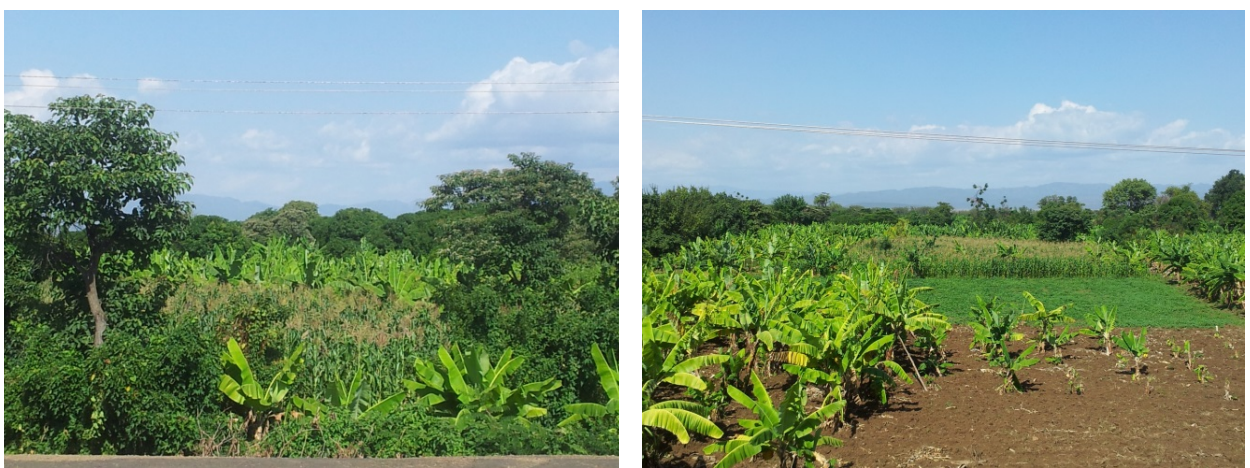

Figure 5. Intercropping agroforestry practices (maize, banana, mango, vegies, etc.)
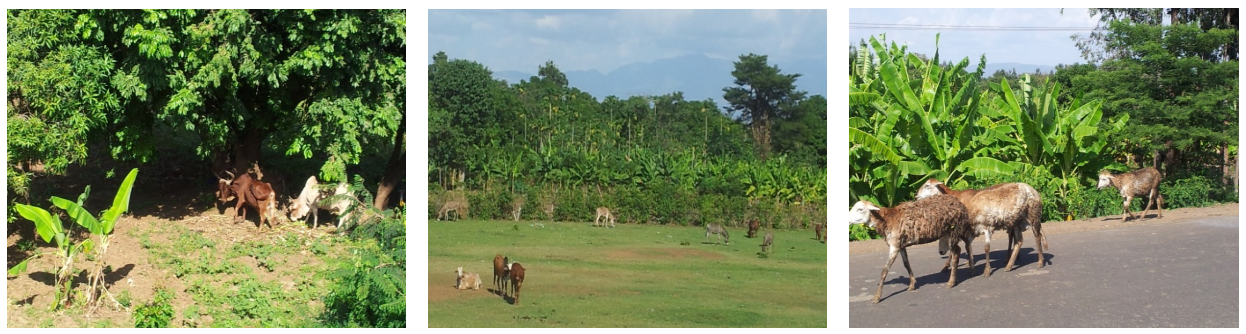

Figure 6. Livestock related agroforestry practices in Lante. 
non-agroforestry practices (Figure 8). In terms of dietary diversification agroforestry has given more varieties of food than other forms of agriculture. Once established, agroforestry practices also need less intensive farm management activities and this has favored the local communities to have more time to perform other off-farm income generation activities. As a result of this, it was also mentioned by the participants as children's school enrolment rate is better in agroforestry practitioners as compared to others as the demand for labor is low in agroforestry practices when compared with other farming activities. The benefits of agroforestry practices in terms of drought resistance was also rated high as trees can tolerate short and longer term water stress while providing all the environmental, nutritional and economic benefits to the practitioners and the locality (Figure 7, Figure 8).
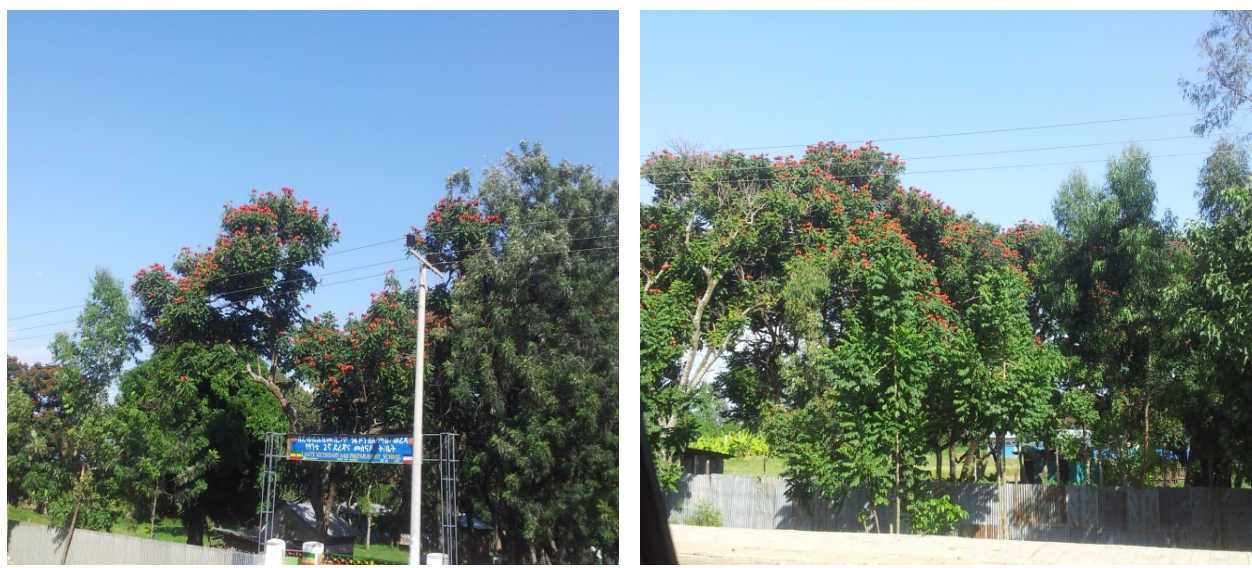

Figure 7. Agroforestry and its ornamental value in Lante.

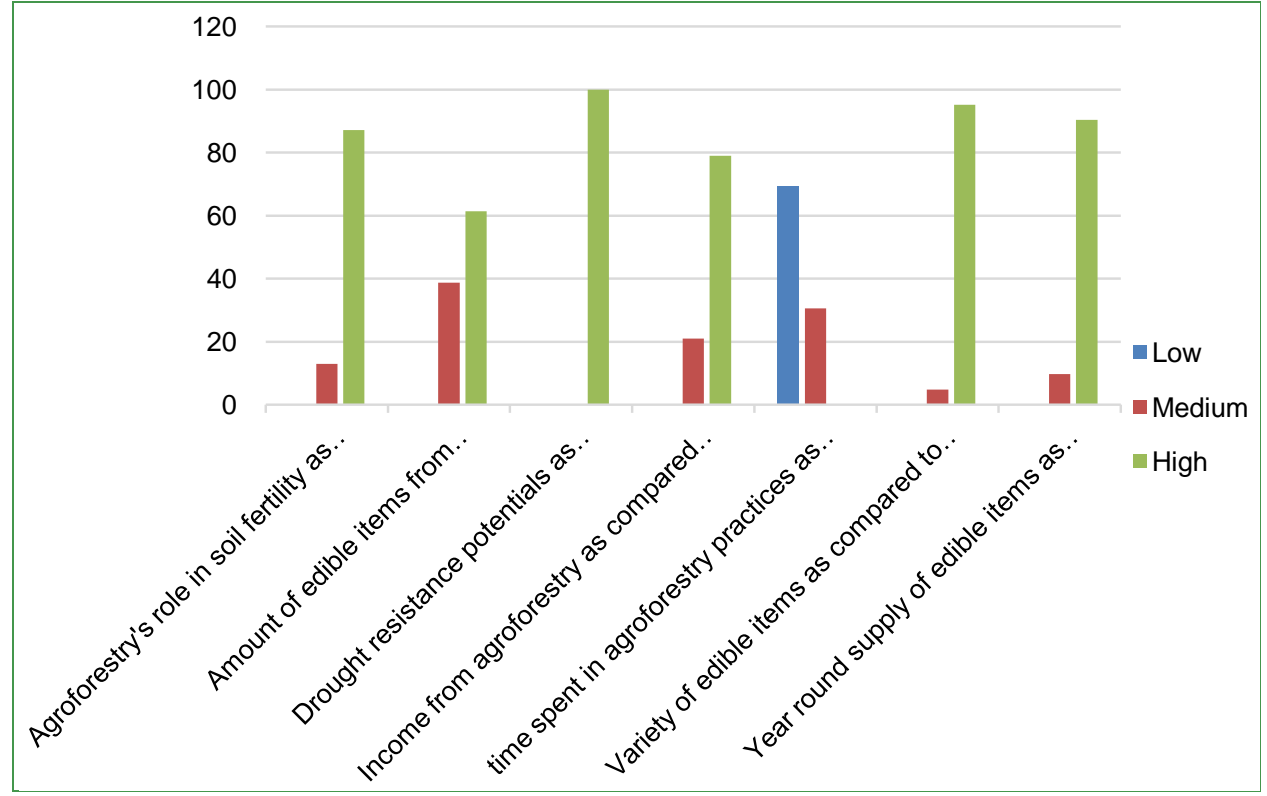

Figure 8. Perception of local communities towards agroforestry as compared to other forms of agriculture (in \%). 


\section{Conclusion}

There is vast evidence that agroforestry practices to play a pivotal role in sustaining ecological balances by providing different ecosystem services. The practices are also known to increase agricultural productivity, enhance household food security and increased income from the tree and non-tree components of the system. Their role in livelihoods development, climate change mitigation, biodiversity conservation and green economy development is also vital for the development of human capital on the face of the earth. The indigenous knowledge and practices of agroforestry, however, are being eroded as a result of the increased need of the ever increasing human population. However, there is still a hope if advanced policy actions in the environmental governance, land tenure, investments and market linkages are placed so that agroforestry systems will continue to deliver sustainable improvements to the food security efforts of the nation. Policies should also consider mechanisms to engage women in decisionmaking since that will help to improve the adoption of home garden agroforestry practices as well. In addition to this, the issue of agroforestry has to be considered as part of the country's biodiversity conservation and other land management strategies.

\section{References}

[1] Rossier, C. and Lake, F. (2014) Indigenous Traditional Ecological Knowledge in Agroforestry. USDA National Agroforestry Center and US Forest Service, SW, Washington DC.

[2] Jose, S. (2009) Agroforestry for Ecosystem Services and Environmental Benefits: An Overview. Agroforestry Systems, 76, 1-10.

[3] Garrity, D.P. (2004) Agroforestry and the Achievement of the Millennium Development Goals. Agroforestry Systems, 61, 5-17. https://doi.org/10.1023/B:AGFO.0000028986.37502.7c

[4] Mbow, C. (2015) Agroforestry Can Form an Effective, Efficient and Fair Pathway to Achieve Food Security and Agricultural Sustainability in Africa. Climate Change and Development-ICRAF, World Agroforestry Centre, Nairobi.

[5] Madalcho, A.B. and Tefera, M.T. (2016) Management of Traditional Agroforestry Practices in Gununo Watershed in Wolaita Zone, Ethiopia. Forest Res, 5, 163. https://doi.org/10.4172/2168-9776.1000163

[6] ECRGE (Ethiopia's Climate-Resilient Green Economy) (2011) Federal Democratic Republic of Ethiopia, Green Economy Strategy. Addis Ababa.

[7] Nair PKR (1993) An Introduction to Agroforestry. Kluwer Academic Publisher with Cooperation ICRAF, Dordrecht, London, 489. https://doi.org/10.1007/978-94-011-1608-4

[8] ICRAF (World Agroforestry Centre) (2006) Agroforestry for Improved Livelihoods and Natural Resources Conservation. An Agroforestry Policy Brief. Nairobi.

[9] FAO (2015) Agroforestry. Rome. http://www.fao.org/forestry/agroforestry/80338/en/

[10] Karki, A. (2016) Agroforestry and Its Benefits. RESET. https://en.reset.org/knowledge/agroforestry-and-its-benefits

[11] AAC (Agriculture and Agro-food Agency of the Government of Canada) (2014) Benefits of Agroforestry. Montreal.

[12] FDRE-PCC (Federal Democratic Republic of Ethiopia, Population Census Commission) (2008) Summary and Statistical Report of the 2007 Population and Housing Census. Addis Ababa. 
[13] LOA (Lante Office of Agriculture) (2016) Basic Information of Lante. Lante, Arba Minch.

[14] WBSPP (Woody Biomass Strategic Planning Project) (2005) Location Map of Lante. On CD. Addis Ababa.

\section{Submit or recommend next manuscript to OALib Journal and we will provide best} service for you:

- Publication frequency: Monthly

- 9 subject areas of science, technology and medicine

- Fair and rigorous peer-review system

- Fast publication process

- Article promotion in various social networking sites (LinkedIn, Facebook, Twitter, etc.)

- Maximum dissemination of your research work

Submit Your Paper Online: Click Here to Submit

Or Contact service@oalib.com 